\title{
The Implementation of Traditional Games to Improve the Social Emotional Early Childhood
}

\author{
${ }^{1}$ Putu Indah Lestari, ${ }^{2}$ Elizabeth Prima \\ ${ }^{1,2}$ Teacher Education of Early Childhood Education Program \\ Universitas Dhyana Pura \\ Email: indahlestari@undhirabali.ac.id
}

(Received: October-2017; Reviewed: October-2017; Accepted: November-2017; Published: November-2017)

(C2017 -EST Graduate Program Universitas Negeri Makassar. This is an article with open access under license CC BY-NC-4.0 (https://creativecommons.org/licenses/by-nc/4.0/ ).

\begin{abstract}
The aims of this study was to improve the social emotional early childhood through the traditional game. This research was conducted on the children of group B TK Pradnyandari III Kerobokan in the academic year 2016 / 2017. This research used Classroom Action Research design with observation method. The subjects of this study were 22 children of group B1 TK Pradnyandari III Kerobokan consisting of 11 sons and 11 daughters. The object of research is the application of traditional children's games to increase social emotional early childhood. The results og this research as in Cycle I, 14 children (63.64\%) reached the completeness learning mastery, 8 children (36.36\%) had not reached. In Cycle II, 20 children (90,91\%) reached the learning mastery, leaving only 2 children (9,09\%) had not reached. The implementation of traditional games can enhance children's social emotional skill. Based on the research findings there was an improvement of $27.27 \%$ learning mastery of the children from Cycle I to Cycle II. This means that the application of traditional games can improve children's social emotional development. Traditional games can be piloted in other areas of development skill in early childhood education.
\end{abstract}

Keywords: social emotional;early childhood; traditional games

\section{INTRODUCTION}

Early Childhood Education is essentially an education that is organized with the aim of facilitating the growth and development of children as a whole that emphasizes the development of all aspects of the child's personality. Every child has a number of potentials, whether physical, biological, cognitive, or emotionally social (Desmita, 2009). Early childhood education should provide various activities that can develop various aspects of development including cognitive, language, social, and emotional aspects. Aspects of emotional development and socialization in children become a very important part in shaping behavior in children. One form of game that can be used to improve the social and emotional skill of early childhood is the traditional game. Traditional games can create flexibility in play so that children can be more flexible in playing. One reason of researchers to use traditional games is the development of gadget or game technology that is more fun to play compared to traditional games. Children are more focused on gaming than traditional games. In addition, traditional games are already rarely played at school. 
Playing will stimulate the child's emotional development in order to learn to accept, express and solve problems in a positive way. Playing is the most important means for the development of social skills and expanding empathy towards others and reducing the attitude of egocentrism (Harly, 2014). The traditional game is a form of game or sport activity that evolves from a certain community habit. Kurniawati (2014) in her research showed that traditional children's games can stimulate children to develop cooperation, help children adjust, interact in a positive way, can condition the child in selfcontrol, develop empathy attitude toward friends, obey the rules, and can appreciate others.

Cahyono (2011) points out a number of characters possessed by traditional games that are able to form a positive character that is: traditional games tend to use the facility in the environment without buying it so children need high imagination and creativity to create game tools, the traditional game of children involves so many players' demands interaction skills among the players in it, traditional games have certain moral messages such as shared values, honesty, responsibility, attitude of the chest, the drive for achievement, and obedience to the rules.

Part of the form of social behavior that developed in early childhood, is a behavior formed on the basis of the foundation placed in infancy. The foundation laid in early childhood will determine how children adapt to others. Children can express all feelings and expectations through play (Mutiah, 2012). Through playing children acquire and process information about new things and practicing through the existing skills, children also learn to be self-centered, understand life, and understand the world. Playing for children of Kindergarten is a fun activity that brings hope and anticipation about a joyful world (Handayani, 2013). Social emotional development includes a) Selfawareness, b). A sense of responsibility for others, and c). Proportional behavior.

Relevant research used in this study is the first by Harly (2014) which stated that the social emotional improvement of children aged 5-6 years after a traditional game in TK Bruder Nusa Indah Pontianak in academic year 20132014 could already be said "good" with an increase in the average $80 \%$. The evidenced by the average social ability of children cycle I was
$47 \%$ and in cycle II got an average of $82 \%$. Secondly, according to Handayani (2013) stating that there was an increase of social attitude of child Group B TK Astiti Dharma Penatih Denpasar after applying traditional game of Meong-meongan with initial average value was 48,221 (25\%) with good enough classification, increased to $76,088(90 \%)$ at the end of cycle II with very good classification. Third, Perdani (2014) concluded that the social skills of the children of group B TK Nurul Ain, Desa Gue Gajah, Aceh Besar through traditional game play method could increase by $42.13 \%$ from the pre-intervention grade average and $54.13 \%$ on the results of the post test.

In the district of North Kuta there are 52 kindergartens. One of the kindergartens was TK Pradnyandari III Kerobokan. TK Pradnyandari III Kerobokan has been established since 2004. In the academic year 2016-2017 there were 44 students of group B. Learning model used in TK Pradnyandari III was still classical. The problems that were found during the observation in Group B1 which consisted of 22 people; 11 girls and 11 boys was $63,647 \%$ of the total students were still low at social emotionaldevelopment. Moreover, the children in TK Pradnyandari III had never received any model of learning by applying traditional games in learning. During the observation of the social emotionalabilities of children, there were many children who showed low ability to adjust the situations. Besides responsibilities of children were also still low. Teachers in the B1 group taught the students with the lecture method so that the learning atmosphere became less active. Based on the results of observation on the children of Group B 1 TK Prandnyandari III Kerobokan then this study aims to figure out the improvement of the social emotional development of early childhood through traditional games. This research was a classroom action research with 2 cycles using observation and interview method. The application of traditional games is expected to improve the social emotionaldevelopment of children, become a reference for teachers in carrying out classroom learning activities, and and also preserve traditional game types.

The purpose of this study are: 1) To know the effort to improve social emotional early childhood through the traditional game. 2) to figur out The obstacles faced in improving the social emotional development of early childhood 
through traditional games. 3) To know the social emotional improvement of early childhood after the implemenattion of traditional game after 2 cycles.

\section{METHOD}

This study used a classroom action research design that generally aimed to improve social development of early childhood. The study was designed in two cycles. Each cycle consisted of four stages: planning, action, observation / evaluation, and reflection. The subjects of this study were 22 children of B1 TK Prandnyandari III Kerobokan group consisting of 11 girls and 11 boys. The reason for taking the subject due to the lack of application of traditional children's games so that the excitement of students in socializing less and impact on the low emotional child. This was obtained from the results of preliminary observation, in group B1, 65,7\% of the total students were still low at social emotional development. The object of this classroom action research conducted on the subject of research at the level of Kindergarten is the implementation of traditional games in the process of early childhood learning to improve the social emotional development of children. Data collection method used in this research was through observation and interview. The process of collecting data through this observational technique using guidelines rubric to record data about social emotional development that indicated early childhood. The process of observation assisted by the instrument in the form of an observation questionnaire with research indicators were: a) Playing with peers; b) Respect the rights / opinions / works of others; and c) Expressing emotions appropriate to existing conditions (happy-sad-enthusiastic). While in carrying out unstructured observation, observations did not provide a list of advance aspects of the observed. In this case observations record all the behavior that was considered important in an observation period.

\section{FINDINGS AND DISCUSSION}

\section{Findings}

\section{Cycle I}

Cycle I with the theme of Tanah Airku was planned for 4 meetings, each meeting was implemented based on the learning scenario. The research process used observational methods at each meeting to assess the social emotional development of children. In detail the average value of the child's social emotional development in following the learning activities through traditional children's games in Cycle I was set out in Table 1 below

Tabel 1 Data of the Cycle I

\begin{tabular}{lc}
\hline & $\begin{array}{c}\text { Social Emotional } \\
\text { Development of Early } \\
\text { childhood }\end{array}$ \\
\hline $\mathrm{N}$ & 22 \\
\hline Mean & 8,05 \\
\hline Median & 8,38 \\
\hline Modus & 9 \\
\hline Std Deviasi & 2,18 \\
\hline Minimum & 4,5 \\
\hline Maximum & 10,5 \\
\hline
\end{tabular}

Scores of respondents' measurements obtained the highest score was 10.5 of the highest possible score reached 12 . The lowest respondent score was 4.5 of the lowest possible score was 4. The results of observation of children's social emotional development were converted by using the Benchmark Reference Assessment(PAP) with five scale. The results of the social emotional development outcomes in Cycle I could be seen in Table 2 as follows: 
Tabel 2 Result of Social Emotional Developments of Children in Cycle I

\begin{tabular}{cccccc}
\hline No & $\begin{array}{c}\text { Percentage } \\
\text { of Mastery }\end{array}$ & total & Persentage & Remark & Completeness \\
\cline { 1 - 5 } 1 & $0-54$ & 2 & 9,09 & Very Low & \multirow{2}{*}{ Not complete } \\
\hline 2 & $55-64$ & 6 & 27,27 & Low & \\
\cline { 1 - 5 } 3 & $67-79$ & 13 & 59,09 & Average & \multirow{2}{*}{ complete } \\
\cline { 1 - 5 } 5 & $80-89$ & 1 & 4,55 & High & \\
\hline 5 & $90-100$ & 0 & 0 & Very High & \\
\hline
\end{tabular}

From Table 2 above, it can be observed that from 22 children, 2 children $(9.09 \%)$ received very low category, 6 children $(27.27 \%)$ achieved low category, 13 children $(59.09 \%)$ social emotional gets the average category, as much as 1 child (4.55\%) with high category, and no one child that level of social emotional development reach very high category. Of the 22 children, 14 children $(63.64 \%)$ have achieved completeness of learning, 8 children $(36.36 \%)$ have not reached mastery learning. For more details can be drawn on the polygon graph below:

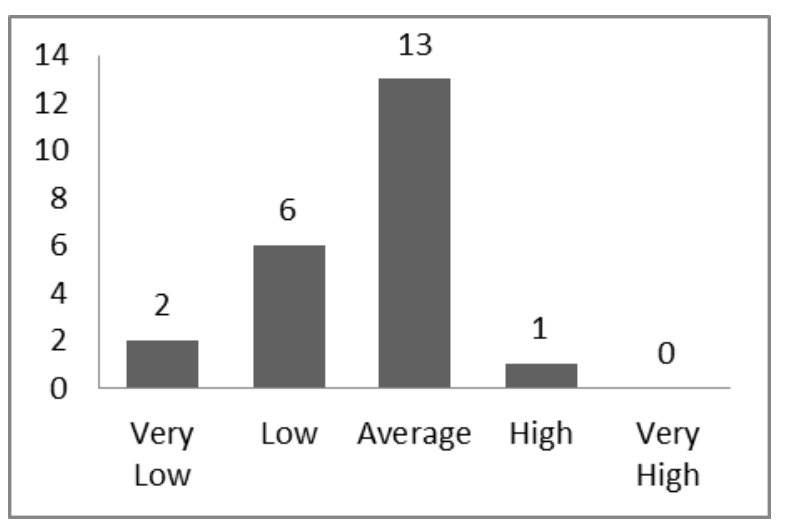

Figure 1 Graph of Social Emotional Development Result of Cycle I

In general, the level of social emotional development of TK Pradnyandari III Kerobokan has reached the average success with average and high category. At the end of Cycle I has reached the completeness of $63.64 \%$. The result of the social development of children in Cycle I has not reached the minimum mastery of $80 \%$ so that the research continued in Cycle II.
The implementation of Cycle II was not much different from the implementation in Cycle I. The things prepared in Cycle II include the Weekly Activity Plan (RKM), Daily Activity Plan (RKH), learning scenario, instructional media, and social emotional development assessment rubric. Cycle II was designed for 4 meetings with the theme of "Tanah Airku", each meeting was implemented based on the learning scenario. In detail the average value of children's social emotional development in following the learning activities through traditional children's games in Cycle II was set out in Table 3 below:

Tabel 3 Data of Cycle II

\begin{tabular}{ll}
\hline & $\begin{array}{c}\text { Social Emotional } \\
\text { Development of Early } \\
\text { childhood }\end{array}$ \\
\hline $\mathrm{N}$ & 22 \\
\hline Mean & 9,68 \\
\hline Median & 9,75 \\
\hline Modus & 9,50 \\
\hline Std Deviasi & 1,19 \\
\hline Minimum & 7 \\
\hline Maksimum & 12 \\
\hline
\end{tabular}

Scores of respondents' measurements obtained the highest score is 12 of the highest possible score was 12 . The lowest respondent score is 7 of the lowest possible score was 4 . The results of observation of social emotional development of children were converted by using the guidance of the conversion of Benchmark . Reference Assessment (PAP) scale five. The results of the child's social emotional development in Cycle II can be seen in Table 4 as follows:

\section{Cycle II}


Tabel 4 Result of Social Emotional Developments of Children in Cycle II

\begin{tabular}{cccccc}
\hline No & $\begin{array}{c}\text { Percentage } \\
\text { of Mastery }\end{array}$ & total & Persentage & Remark & Completeness \\
\hline 1 & $0-54$ & 0 & 0 & Very Low & \multirow{2}{*}{ Not complete } \\
\hline 2 & $55-64$ & 2 & 9,09 & Low & \\
\hline 3 & $67-79$ & 8 & 36,36 & Average & \multirow{2}{*}{ complete } \\
\hline 4 & $80-89$ & 9 & 40,91 & High & \\
\hline 5 & $90-100$ & 3 & 13,64 & Very High & \\
\hline
\end{tabular}

From Table 4 above, it can be observed that out of 22 children, none of the children received very low categories. There were still 2 children $(9.09 \%)$ got low category, 8 children $(36.36 \%)$ achievement of social emotional development got medium category, 9 children $(40.91 \%)$ with high category, and 3 children $(13.64 \%)$ the level of social emotional development reached very high category. From 22 children, 20 children $(90.91 \%)$ had achieved completeness. There were only 2 children (9.09\%) who had not achieved completeness of learning. For more details, can be illustrated in Figure 2 below

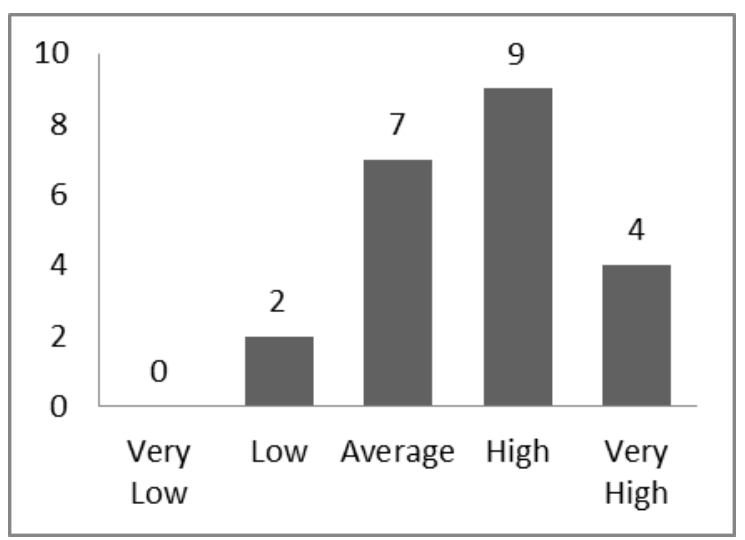

Figure 2 Graph of Social Emotional

Development Result of Cycle II

The results of monitoring as described above showed that in general the level of social emotional development of TK Pradnyandari III Kerobokan has reached the average success in the category of medium, high, and very high. This means that the application of traditional children's games could improve the social emotional development of children because at the end of Cycle II reached the completeness of $90.91 \%$ with most of the children get high and very high category

\section{Discussion}

Empirical findings obtained by researchers in the field of social emotional aspects of the TK Pradnyandari III Group B1 in Cycle I showed that of 22 children, 14 children $(63.64 \%)$ had reached mastery learning, 8 children $(36.36 \%)$ has not reached mastery learn. Many children got difficulties with indicators of respect for the rights / works / opinions of others. Children rarely valued the opinions of others. In addition, there were still some children who shyly expressed emotions in accordance with existing conditions. And did not want to engage in playing activities. Attempts to overcome this was the teacher's personal approach, involving peers to play. Learning together in groups with peers was one of the characteristics of competency-based learning, through interaction and communication activities, students became actively learning, they became effective. Cooperation in groups with peer tutors could be linked to values so that cooperation becomes more intensive and students can achieve their competence. According to Arikunto (2002) sometimes a student is more receptive to the information given by a friend or friend because there is no reluctance or shame to ask, the teacher can ask for help to the children who explain to his friends. So over time, the child is willing to be involved in the learning process.

Empirical findings in Cycle II for the social emotional aspect of the children, in general the level of social emotional development of TK Pradnyandari III Kerobokan had achieved average success with medium, high, and very high category. This means that the application of traditional children's games could improve the social emotional development of children because at the end of Cycle II had reached the completeness of $90.91 \%$ with most of the children got high and very high category. Results of social development of children in Cycle II had reached a minimum mastery of 
$80 \%$. An increase in social emotional development of children was $27.27 \%$. Every aspect in the social emotional development of children in Cycle II also increased compared to that in Cycle I. This means that there was a social emotional improvement in Kindergarten group B children, through the application of traditional children's games (deduplak, ladders, clogs, and congklak) after 2 cycles. This is in line with research conducted by Kurniati (2011), which stated that traditional child games could stimulate children to develop cooperation, help children adjust, and interact in a positive way. Traditional games could improve problem solving ability in children, stimulate the development of language, verbal skills, social skills, emotional expression container was good for children, and improve learning motivation of children. According to Harly (2014) social emotional improvement of children aged 5-6 years after the traditional games includes a child has the ability to cooperate with friends, children's ability to show tolerance, the ability of children to understand the rules and discipline in the traditional games, the ability of children to show gesture persistent (not easily give up).

\section{CONCLUSION AND SUGGESTION}

The conclusions that can be drawn from this research are:

1. The application of traditional games could improve the social emotional of the children in Group B1 TK Pradnyandari III Kerobokan with each child has reached the minimum completeness criteria of 20 children $(90.91 \%)$ with moderate success category, high and very high at the end of Cycle II.

2. Constraints faced at the time of research include: there were still children who rarely value the opinions / works of others. In addition there were still some children who shyly express emotions in accordance with existing conditions. and do not want to be involved in learning activities. The effort to overcome them is the teacher's personal approach, involving peers to play.

3. There is an improvement in early childhood of the social emotional development through the implementation of traditional games after 2 cycles, which was $27.27 \%$
Suggestions that can be asked in the continuation of this research are:

1. Implementation of traditional children's games to be more effective, educators should first identify the characteristics of students and the characteristics of teaching materials, it can be done by way of initial observation of learners

2. Traditional children's game implementation can be piloted in other areas of development in early childhood education.

\section{REFERENCES}

Cahyono, N. (2011) .Transformasi Permainan Anak Indonesia. Artikel. http://permatanusantara.blogspot.com. Diakses pada tanggal 25 September 2013.

Handayani, K. D., Dantes, N., \& Lasmawan, W. (2013). Penerapan permainan tradisional meong-meongan Untuk perkembangan sikap sosial anak Kelompok B Taman Kanak-kanak Astiti Dharma Penatih Denpasar. Jurnal Pendidikan Dasar, 3(1).

Harly, S. L. C., Syukri, M., \& Yuniarni, D. (2014). Peningkatan Perkembangan Sosial Emosional Melalui Metode Bermain Permainan Tradisional Pada Anak Usia 56 Tahun. Jurnal Pendidikan Dan Pembelajaran, 3(8).

Kurniawati, M. W., \& Dwijiastuti, M. G. (2014). Peningkatan Keterampilan Sosial Melalui Permainan Tradisional Pada Anak Kelompok A TK Cemara Dua Surakarta Tahun Ajaran 2013/2014. Kumara Cendekia, 2(1).

Madya, S. (2006). Teori dan Praktik Penelitian Tindakan (Action Research). Bandung: Alfabeta.

Mutiah, Diana. (2012). Psikologi Bermain Anak Usia Dini. Jakarta: Kencana Prenada Media Grup.

Permendikbud. (2014). Standar Nasional Pendidikan Anak Usia Dini. Jakarta: Departemen Pendidikan Nasional.

Pribadi, B. A. (2009). Model Desain Sistem Pembelajaran. Jakarta: PT Dian Rakyat.

Rahayu, D., Ichas, S., \& Sutini, A. (2016). Peningkatan Keterampilan Sosial Anak Usia Dini Melalui Permainan Tradisional. Jurnal PGPAUD Kampus Cibiru, 4(2).

Seriati, N. N., \& Hayati, N. (2012). Permainan Tradisional Jawa Gerak dan Lagu Untuk 
Menstimulasi Keterampilan Sosial Anak Usia Dini. Naskah Publikasi.

Suhardjono (2009). Penelitian Tindakan Kelas \& Tindakan Sekolah. Malang: Cakrawala Indonesia.

Sujiono, Yuliani N. (2009). Konsep Dasar Pendidikan Dasar Anak Usia Dini.Jakarta : PT Indeks

Uno, H.B. (2006). Perencanaan Pembelajaran. Jakarta :Bumi Aksara.

UU RI No. 20 (2003) Sistem Pendidikan Nasional. 